\title{
Research on Rural Cultural Space Reconstruction Based on the Theory of Space Production
}

\author{
Xianghu Zhong ${ }^{1}$ \\ ${ }^{1}$ College of History and Culture, Hubei Normal University , 435002, China
}

\begin{abstract}
Rural construction has been paid attention to by the country, and different strategies have been adopted at different stages. The rural revitalization proposed in the new era is a comprehensive revitalization including culture. Based on the three spatial concepts of space perception, space conception and space reproduction proposed by Lefebvre, the article takes the construction of the sensible space, conceptual space and living space of rural culture as the important content of the reconstruction of rural cultural space. From the ecological, historical and subjective perspective of the rural cultural space, this paper explores the internal logic of the reconstruction of the modern rural cultural space. That is, to follow the ecological balance of the cultural space, and to meet the living requirements of the cultural space. Rural cultural space reconstruction should respect its the historical tradition and awaken the memory of homesickness.At same time,there is rural residents' cultural consciousness .Cultural reconstruction needs toreflect their subjective status.
\end{abstract}

\section{Situation and Dilemma of Rural}

\section{Culture}

China has attached importance to rural construction for a long time.But "rural reconstruction is a hundred years of pain in China ". ${ }^{[1]}$ From the end of the 19th century, When the Chinese countryside was "thrown into" the world,the countryside is the "cultural space as a problem ". Because the main body carrying civilization is too late for cultural renewal, China's rural is bankruptcy, cultural decline. From the rural construction movement of the Republic of China to the people's commune movement after the founding of new China, the rural crisis persists althrough the countryside is not decaying. Especially since the founding of new China, rural cultural spaces are being squeezed. In particular, the original social relations based on family suffered a huge impact. Since the reform and opening up, the modernization policy dominated by industrialization and urbanization has drained the country' s youth.So rural is hollowing and empty-nesting are deteriorating. Rural traditions are disappearing, too. Ancient villages are also dying out in urbanization. There are signs that China's countryside has really started to decline. ${ }^{[2]}$ The essence of rural decline is cultural decline. In his book The End of Peasants, Henri Mendras pointed out that the heart of rural decline lies in cultural fragmentation :" The causes of degradation and decline are not, as is often assumed, economic exploitation, but the cultural environment of the victims which is dismenmbered. ${ }^{[3]}$
In view of the plight of rural development, a series of measures such as new rural construction and beautiful rural construction are put forward and implemented.Especially the "strategy of rural revitalization" was put forward by the Nineteenth CPC National Congress, which once again sounded the horn of rural construction. Rural revitalization is a comprehensive revitalization, including rural culture. Therefore, the author believes that the key to rural revitalization in China lies in the revitalization of rural culture, and the revitalization of rural culture is based on the reconstruction of rural cultural space with rural cultural landscape as its content.

\section{Conceptual and theoretical development of cultural space}

Henri Lefebvre first put forward the word "cultural space" in "the production of space ", and thought that" space is produced through the conscious activities of human subjects ", and cultural space must be continued and developed vertically through time. ${ }^{[4]}$ The concept of "cultural space" was also proposed in the Expert Consultation on the International Protection of Civil Cultural Space held in Marrakech in 1997. In 1998, UNESCO defined "cultural space" as a place to focus on the display of intangible cultural heritage from a nonlegacy perspective, concentrating the place and time of folk and traditional cultural activities, the existence of which depends on the existence of cultural activities carried out in traditional ways.

\footnotetext{
* Corresponding author: author@e-mail.org
} 
In 2005," Opinions on Strengthening the Protection of Intangible Cultural Heritage in China "published by the country summarized" cultural space "as a place to hold or display traditional cultural activities or traditional cultural expressions. From the perspective of non-legacy protection, The professor who is Bing' an $\mathrm{Wu}$ expounds the folk culture space," refers to the area where a certain folk traditional cultural activity is concentrated, or the time selected by a certain cultural event ",and the folk culture space" is a place or a series of places where traditional or folk cultural expressions are carried out regularly ". Bingzhong Gao who is the another professor of Anthropology holds that: cultural space is the place, scene and landscape that embodies meaning and value, which is composed of place and meaning symbol and value carrier. A key meaning of cultural space is "cultural space with core symbol ", which means that a society can be grasped with the basic content of a culture because of its cultural uniqueness--which is manifested in a certain symbol or image. It has the symbol of concentrated value and is recognized by the members, which is the basis of the collective consciousness of the community.

Based on the public connotation of cultural space and the participants, the concept of rural public cultural space has been put forward by scholars. Chen Bo believes that rural public cultural space is the place and carrier for rural residents to participate in cultural life, which has both geographical spatial significance and sociological sense of public spirit and belonging consciousness. It also sums up the concrete contents of rural public cultural space, including the public cultural space with daily cultural life, traditional cultural activities and government cultural welfare. $\mathrm{Lu} \mathrm{Lu}$ and Zhiping Zhu summarized the characteristics of rural public cultural space, that is transitional and fragmented. Jingzhong Ye analyzed the reason of the decline of rural public cultural space which is the unilateral myth of development discourse. In view of this situation, Xuefeng He put forward the view that the current rural problem is mainly cultural construction.

The reconstruction of rural cultural space becomes the spiritual core and foundation of the continuation of rural society and the creative development of rural society.And it is an important part and field reflecting the material life and spiritual life of rural residents. The reconstruction of rural cultural space must be based on the regional characteristics of the countryside, reflecting the basic cultural elements such as the geography and climate, folklore and belief, lifestyle and cultural concept of the countryside, and reflecting the suitability of the living environment, the obvious differences of cultural characteristics among the villages, and the complex combination of production and life superposition.

\section{Content of Rural Cultural Space Reconstruction}

Henri Lefebvre has put forward three-fold space, such as space perception, space conception and space reappearance, and its interrelation. ${ }^{[5]}$ Space is a complex of material practical activities and spiritual activities, social production and social relations, reality and imagination, openness and reorganization. Lefebvre's three-fold feature of space provides inspiration for us to study the content of rural cultural space reconstruction. The rural cultural space reconstruction must be based on rural reality .It is a starting point to rebuild the history of the past, rural culture direction and blueprint of the creative presupposition of the future development. It is not only the inheritance of excellent traditional culture, but also the creative development and creative transformation of excellent traditional culture. The reconstruction of rural cultural space includes the following aspects:

Firstly, the perceptual space is reconstructed. The author thinks that the perceptual space of rural culture mainly refers to the material space, including the geographical environment of the countryside, the rural boundary, the pattern of streets and alleys, the building space and so on. The geographical environment of the countryside includes the natural environment such as mountains, water and weather. The reconstruction of the rural cultural space must be based on the geographical environment of the countryside in order to embody the realm of "the unity of nature and man". Chinese pursue "the unity of nature and man" in the traditional culture of China.And "the unity of nature and man" also be the requirement of nature and ecology in the reconstruction of the rural cultural space, and it expresses the harmony between man and nature. Rural boundaries include rural walls, rivers, ditches, mountains and so on, reflecting the regional nature, uniqueness and difference of rural culture. Rural street pattern and architectural space, including living, sacrificial, commercial, interpersonal communication and other physical space, are the material carriers of rural culture.To some extent,these are the essence of the existing ancient village culture. So the reconstruction of rural cultural space needs to do a good job of rural street and architectural space layout, which is integration of ecology, people in the culture.

Secondly, conceptual space is reconstructed. Conceptual space includes rural folklore, folk activities, festivals and other traditional cultural matters. These traditional cultural matters are the carriers of rural cultural development, the history of rural development, and the embodiment of rural collective memory and collective spiritual value. Then the task of rural cultural space reconstruction is to excavate, arrange and record these cultural matters in the countryside, reshape the collective identity consciousness of the rural main body, construct the social atmosphere and imagination space of "remembering to live homesickness ".And in the end , the entity content can be formed that can be used for the narrative expression of the rural cultural space. "Tradition is the cultural heritage of a society and an ideographic symbol of systems, beliefs, values and ways of behaviour created by mankind in the past; it maintains a certain continuity and identity between generations, between one historical stage and another;it constitutes a cultural code for the creation and re-creation of a society, and brings order and meaning to human existence ," Hill said." $[6]$ 
Thirdly, the living space is reconstructed. The living space includes traditional handicraft skills, rural language, leisure and entertainment, life communication and so on. In particular, the traditional handicraft skills, including making iron, textile, stone carving, making kite and fireworks, are to some extent the embodiment of the traditional rural life style.And they are integral parts of the traditional rural culture. Teahouse, ancestral hall, field, fire pond, stove hall, pond, well, cinema, book house and other living and entertainment places are not only the carriers of rural life style, but also the field where rural residents interact with each other. They are not only the foundation of the growth and development of rural culture, but also the space for the inheritance and dissemination of rural culture. Therefore, the reconstruction of rural cultural space needs to take the living space as the carrier, restore the living state of rural residents, highlight the characteristics of rural culture; at the same time, the reconstructed rural cultural space links up the modern turn of rural living space, expands the function of value reproduction of living space, and reflects the effective integration of tradition and modern living space.

\section{The Internal Logic of the Reconstruction of Rural Cultural Space}

During the transformation and development of rural modernization, its cultural space faces many problems.In the process of rural renewal, if the village hasn't produced a suitable space, so it is an empty words to "change the way of life" and "change the society". ${ }^{[7]}$ Rural cultural space includes both material space and spiritual space, as well as productive space and living space. The reconstruction of rural cultural space needs to be carried out systematically based on the rural reality.And the unity of material, spiritual and social aspects must be revealed. ${ }^{[8]}$ Therefore, this paper explores the internal logic of the reconstruction of modern rural cultural space from the perspective of ecological, historical and subjective.

\subsection{Following the ecological balance of cultural space and meeting the requirements of the living state of cultural space}

"The original ecological culture is the culture in the people's life, the unique culture rooted in a certain region, and the living culture of keeping pace with the times." [9] The cultural ecological space of villages is diversified, differentiated and local. At same time,it is both natural field and human field. In the process of the reconstruction and production of rural cultural space, the ecological balance of rural culture must be maintained. Reconstruction of rural cultural space is not the "circle guard" of "shards" or "isolated islands" of rural culture, ${ }^{[10]}$ but a holistic reconstruction.It focuses on not only just culture itself, but also the social, economic, ecological and other structural environments on which culture depends and responds.It is a living cultural space that integrates the production, life and cultural background of villagers. It is an ongoing, real activity within the cultural space. Mr. Liang Shuming said that the way of creatively reconstruct Chinese rural culture is a method of living in a society. ${ }^{[11]}$ The rural cultural space is reconstructed in the way of rural residents' living.This way can prevent vulgarization and single commercialization of the reconstruction of the rural cultural space .

\subsection{Respecting the historical tradition of rural cultural space, awakening the memory of homesickness}

During the decades of urbanization, the foundation of rural society is gradually deconstructed. The original rural planning used urban design as its planning concept. Urban design emphasises on economic function too much .In the end, that leads to a lack of humanistic care in the countryside, gradually disappearing of the rural differences and highlighting in fluctuation. Therefore, in the reconstruction of rural cultural space, we should abandon the concept of urban design as the goal of planning, overcoming a single market-oriented and economic consideration. The traditional culture, such as the historical relics, space places and folk stories of the countryside,should be excavated, be refined and be confirmed in order to Highlight regional cultural features. "Creative combination of courtyard, ancestral hall, cultural auditorium, schools, ancient buildings, historic blocks, sacrificial activities, agricultural experiences, story-breaking walls and murals, form a narrative space with internal tension and logical order. If you're in it, you get infected. It resonates with people.It's even mindcleaning ${ }^{[12]}$ Meanwhile, the reconstruction of rural cultural space needs to return to the value connotation of spatial aesthetics.Then diversity and difference of multicultural space can resolve the traditional fracture in the process of modernization. The reconstruction of rural cultural space can coordinate the conflict and tension between the living needs of rural residents and the real interests. The return of rural spatial aesthetics should follow two levels which are the "inner" spiritual experience and cultural practice of the "outward" dimension "[13] At last we can realize the reproduction of rural cultural space, awaken the collective memory and emotional identity hidden in the heart of the villagers, and reconstruct the beautiful memory of rural humanistic poetry.

\subsection{The cultural consciousness of rural residents and the participation of subjectivity}

The concept of cultural consciousness put forward by Mr. Fei Xiaotong has important enlightenment to the reconstruction of rural cultural space. The cultural consciousness of rural residents is the self-understanding and self-awakening of the characteristics and values of rural residents' own local culture. Rural cultural space is the collective memory of the generations of residents living in the countryside. And it is an important carrier and force to maintain the rural community. The villagers 
are the main body of rural cultural space, the carrier of cultural elements such as rural belief, habit and social psychology, and the main body of rural cultural inheritance and innovation. In the reconstruction of rural cultural space, it is necessary to embody the presence and dominant position of the rural residents. The villagers should control their own lives by themselves, tell stories of their own and village. Then they can construct a fresh and living rural cultural space, and highlight the subjective position of the villagers themselves. So as to these activities further stimulate the collective identity and participation of the villagers. If the imagination of the other is to make up the rural cultural space, it is difficult to integrate into the real rural life.

\section{Acknowledgment}

This paper is one of the phased results of General project of National Social Science Fund of China: Research on rural Traditional public Cultural Space and Rural Revitalization(NO:19BSH061).

\section{References}

1. 2. Lili Fang. From the perspective of art anthropologyart intervention in the construction of beautiful countryside. National art, 2018.4.

3. Henri Mendras.The End of Peasants.Li Peilin's translation, Social Sciences Literature Press ,2010.

4. Bing Hou, Zhenfang Huang. A Study on the Spatial Form of Cultural Tourism.Tourism Journal ,2011.3.

5. Bin Huang, Bin Lv. Study on the Mechanism of Culture and Creative Industry on the Space Production of Old Town---Taking the Regeneration of Old Town in Nanluogu Lane of Beijing as an Example .Urban Development Research ,2012.6.

6. Edward Shils. Discussion on tradition. Keng Fu, Le Lv , Trans. Shanghai People's Publishing House ,1991.

7. Henry Lefebvre.Space: Social Products and Use Value, Modernity and Space Production, Yaming Bao, editor in chief, Shanghai Education Press, 2003 .

8. Henri Lefebvre. The Production of Space. Oxford UK: Black - wellLtd, 1991.

9. Yonglin Huang.Protection of Intangible Cultural Heritage from the Perspective of "Cultural Ecology ". Cultural heritage,2013.5.

10. (Quili Liu.The Integral Principle of Intangible Cultural Heritage and its Protection .Journal of Guangxi Normal University, 2004.4.

11. Shuming Liang. Complete works of Shuming Liang.Shandong People's Publishing House, 1990.

12. Chunfeng Gao.The way to construct the public cultural space of rural villages from the perspective of narrative expression, Learning forums, 2019.2.

13. Xuan Pei. Construction of spatial aesthetics and the practice of modern cultural representation after it .
Journal of Zhengzhou University (Philosophy and Social Sciences Edition,2014.4. 